\title{
ФОРМУВАННЯ ПРОФЕСІЙНОÏ ІНШОМОВНОЇ КОМПЕТЕНТНОСТІ СТУДЕНТІВ ІНЖЕНЕРНО-ТЕХНІЧНИХ СПЕЦІАЛЬНОСТЕЙ В УМОВАХ ІНФОРМАТИЗАЦІЇ ВИЩОЇ ПРОФЕСІЙНОЇ ОСВІТИ
}

У сучасних умовах інформатизаиії освіти існує необхідність перегляду мети, змісту і технології навчання іноземним мовам, розробки багаторівневої особистісно орієнтованої іниомовної підготовки студентів із застосуванням інформаиійно-комунікаиійних технологій $і$ формування у закладах вищої освіти активного інформащійно-навчального мовного середовища.

Окреслено науково-педагогічну проблему - формування професійної іншомовної компетентності студентів інженерно-технічних спецііальностей як здатності до ділової та міжособистісної інтеракиії в полікультурному середовищі

Аналіз останніх досліджень і публікачій. Теоретичні і практичні аспекти формування професійної іншомовної компетентності студентів досліджували М. Вінник, Л. Гришко, В. Осадчий, Т. Хаткінсон (T. Hutchinson). Теоретичні питання комунікації досліджували М. Каган, C. Спенсер (S. Spencer), К. Фінч (K. Finch.), зокрема і в сфері інформамійних технологій - С. Дюконсон (S. Johnson) та Л. Розенкрени (L. Rosencrance). Проте, наукових пошуків, присвячених аналізу проблеми формування професійноіншомовної компетентності майбутніх інженерів в умовах інформатизаиії, не стали предметом пильного наукового інтересу науковиів.

У дослідженні поставлено завдання здійснити аналіз проблеми формування професійно-іншомовної компетентності майбутніх інженерів з використанням засобів інформаиійних та комунікаиійних технологій в умовах інформатизациї вищої освіти.

Інформатизаиію освіти розглянуто як прочес забезпечення сфери освіти методологією, технологією $i$ практикою розробки та оптимального використання сучасних інформаційних $i$ комунікачійних технологій, орієнтованих на реалізацію психолого-педагогічних иілей навчання. Тому у статті виявлено можсливості застосування засобів інформаційних і комунікаційних технологій в процесі формування професійно-іниомовної компетентності студентів інженерних спеціальностей. Обгрунтовано необхідність використання засобів інформаиійних та комунікаиййнх технологій на профільно-орієнтованих заняттях з іноземної мови та в ичиклі фахових дисцииллін, в прочесі виконання курсових і випускних кваліфікаційних робіт, підготовиі до участі в конференщіях імізснародних проектах.

Ефективне формування професійно-іншомовної компетентності студентів інженерно-технічних спеиіальностей забезпечується використанням засобів інформаційних та комунікаиійних технологій. Професійно-іншомовна компетентність дозволяс вирішувати комунікативні завдання в сфері професійної діяльності, здійснювати іниомовне спілкування з носіями іноземної мови і виконувати пошук $i$ аналіз інформаиїі, необхідної длямайбутньої діяльності.

Ключові слова: професійна іншомовна компетентність, студенти інженерно-технічних спеціальностей, інформаційно-комунікаційні технологї, інформатизаиія вищої професійної освіти.

Нові державні освітні стандарти в сфрері інженерної справи, технологій і технічних наук свідчать про необхідність системних перетворень професійної підготовки інженерних кадрів. Перед освітніми організаціями вищої освіти стоїть завдання створення умов для підготовки фахівців, що володіють широким спектром особистісних і профресійних компетенцій, розвиненими комунікативними навичками, високою інформаційною культурою. Ступінь досягнення результатів освіти залежить від різних чинників і умов, проте пріоритет віддається використанню активних технологій навчання проектно- 
дослідницького характеру та інформатизації освітнього процесу [8, с. 137].

На тлі процесів інтенсивної глобалізації та міжкультурної взаємодії посилюється значущість володіння іншомовною комунікативною компетентністю в сфері професійної діяльності. Необхідність пошуку, аналізу та оцінки майбутніми інженерами великих масивів інформації профресійного змісту, частина з яких представлена іноземною мовою, а також використання інфрормаційно-комунікаційних технологій у професійній діяльності актуалізують необхідність формування професійної іншомовної компетентності в умовах інформатизації вищої професійної освіти. Як доцільно зазначає А. Джурило, створення інформаційно-освітнього середовища засобами інфрормаційнокомунікаційних технологій $€$ обов'язковою умовою реалізації програми бакалаврату та реформування вищої освіти [2, с. 84].

Постановка проблеми у загальному вигляді та їі зв'язок із важливими науковими чи практичними завданнями. Комунікативна роль професіоналів інженерно-технічних спеціальностей у часи об'єднання великих полікультурних та поліетнічних суспільств набуває надзвичайної ролі, що дає право стверджувати - саме зазначені фахівці можуть створити умови для більш комфрортного входження мільйонів пересічних людей у світ інформаційнокомунікаційних технологій. 3 цих очевидних підстав на порядок денний виходить науково-педагогічна проблема, що має актуально перспективний характер - формування професійної іншомовної компетентності студентів інженерно-технічних спеціальностей як здатності ділової та міжособистісної інтеракції, готовності до здійснення функцій ділового та професійного спілкування в полікультурному середовищі тощо.

Аналіз останніх досліджень і публікацій. У системі інноваційної інженерної освіти відбувається цілеспрямоване формування певних знань, умінь і методологічної культури, а також комплексна підготовка і виховання фахівців у галузі техніки і технології до інноваційної інженерної діяльності на основі відповідного змісту, методів навчання і наукомістких освітніх технологій [3, с. 11]. Проблемам і перспективам професійно-іншомовної підготовки студентів закладів вищої освіти присвячені роботи М. Вінника, Л. Гришко, О. Дубініної, В. Круглика, В. Осадчого, В. Седова, 3. Сейдаметової, Д. Щедролосьєва та ін. Нині в іншомовній підготовці пріоритетними є компетентнісний (Н. Гальскова, В. Сафонова, О. Соловова, Дж. Каммінс (J. Cummins), Дж. Фірст (J. Firth), Т. Хаткінсон (T. Hutchinson), С. Савігнон (S. Savignon), М. Сваін (M. Swain і ін.), комунікативний (Є. Пасів, Г. Рогова, В. Кузовлев, Л. Бахман (L. Bachman), Д. Хаймс (D. Hymes), Дж. Манбі (J. Munby), P. Оксфорд (R. Oxford) та ін.), контекстний підходи (А. Вербицький, Н. Патяєва, В. Теніщева, М. Холідей (M. Halliday) та ін.). Поряд з окресленими підходами особистісно зорієнтоване навчання, що передбачає індивідуалізацію навчання, зміну рольових відносин у системі “викладач - студент", знаходить адекватне втілення в змісті і засобах формування професійно-іншомовної компетентності (О.Соловова, Н.Коряковцева та ін.). Теоретичні питання комунікації досліджували С. Алєксандрова, М. Василик, М. Каган, Г. Латфуллин, І. Писаревський, 
Р. Александер (R. Alexander), C. Спенсер (S. Spencer), К. Фінч (K. Finch.), К. Хансен (C. Hansen) та ін., зокрема і в сорері інформаційних технологій P. Абельска, С. Джонсон (S. Johnson) та Л. Розенкренц (L. Rosencrance).

Постановка завдання. Необхідність освоєння майбутніми інженерами величезної кількості світових інформаційних ресурсів, велика частина яких представлена англійською мовою, робить актуальним використання інформаційних та комунікаційних технологій в процесі професійно-іншомовної підготовки. Однак проблема використання засобів інформаційних і комунікаційних технологій в професійно-іншомовній підготовці студентів інженерно-технічних спеціальностей, особливо розроблених в останні роки (технології Веб 2.0, Вікі і блог; навчальні Інтернет-ресурси (hotlist, treasure hunt, webquest i iн.), Moodle), вивчена не повною мірою і вимагає подальших досліджень і власного вирішення.

Виклад основного матеріалу дослідження. Однією з найважливіших умов входження України в світові інтеграційні освітні процеси, без яких на сучасному етапі неможливо забезпечити конкурентоспроможність і сталий інноваційний розвиток вітчизняної профресійної освіти, є інфоорматизація всіх рівнів освіти, розширення доступу до освітніх ресурсів Інтернету, широке впровадження цифрових і електронних засобів навчання нового покоління. Інформатизація освіти, на думку P. Вегенер (R. Wegener) та Дж. Леймейстер (J. Leimeister), $€$ цілеспрямовано організованим процесом забезпечення сорери освіти методологією, технологією і практикою створення та оптимального використання науково-педагогічних, навчально-методичних, програмнотехнологічних розробок, зорієнтованих на реалізацію можливостей інформаційних і комунікаційних технологій, що застосовуються в комфортних і здоров'я зберігаючих умовах [10, с. 386].

Безперервна професійна іншомовна підготовка в інженерній освіті, на думку Л. Матвійчук, актуалізує значущість розмежування видів інженерної діяльності залежно від мети і розв'язуваних фахівцем завдань: виробничотехнологічних, проектно-конструкторських, науково-дослідних та організаційноуправлінських [5, с. 9].

Визначення видів інженерної діяльності повинно впливати на вибір змісту і форм навчання в процесі іншомовної підготовки в закладах вищої профресійної освіти. Аналіз професійних дій, здійснюваних інженерами в різних видах діяльності, $€$ важливою умовою для вибору адекватних форм i технологій навчання на заняттях з іноземної мови для професійних цілей.

Так, науково-дослідницька діяльність інженера зорієнтована на отримання нових наукових даних, що спричиняють відкриття або винахід. Ця діяльність пов'язана з написанням наукових статей, тез, рецензій на публікації технічної тематики, заявок на патенти, інструкцій. Проектно-конструкторська діяльність передбачає розробку технічних пропозицій, ескізних і технічних проектів, результатом чого стає розробка технічної документації. Інженер працює з нормативними актами, довідниками, патентами, інструкціями, специфікаціями. Виробничо-технологічна діяльність інженера охоплює 
більшість етапів життєвого циклу продукції - від впровадження до зняття 3 виробництва. У процесі цього роду занять проводяться виробничі наради, переговори з субпідрядниками та партнерами, а результатами стають технічні заявки на виконання робіт, специфікації, звіти щодо впровадження, ремонту та експлуатації інженерних об'єктів і систем. Організаційно-управлінська діяльність спрямована на управління сукупною інженерною працею [7, с. 371]. Зміст цієї діяльності охоплює здійснення запитів, проведення узгоджень, підготовку розпоряджень, ведення переговорів та ділової переписки 3 замовниками. Очевидно, що іншомовна підготовка студентів інженернотехнічних спеціальностей, які будуть займатися проектно-конструкторською та науково-дослідницькою діяльністю, передбачає масштабну роботу 3 технічними і науковими текстами, закріплення спеціальної термінології, навчання навичкам писемного мовлення. Навчання майбутніх інженерів, задіяних у виробничо-технологічній та організаційно-управлінській діяльності, передбачає збільшення обсягу комунікативних завдань з використанням інтерактивних методів, що моделюють професійні ситуації.

Однак слід пам'ятати, що в умовах глобальних економічних процесів стають все більш ймовірними можливості інтеграції різних видів діяльності інженерів, участь фрахівців у міжнародних проектах (зокрема дослідних) і прагнення в зв'язку з цим підвищити свій професійний рівень, збільшити шанси кар'єрного зростання, для чого потрібне добре володіння іноземною мовою спеціальності [7, с. 371]. Тому не викликає сумніву доцільність «включення” в програми іншомовної підготовки майбутніх фрахівців інженерно-технічних спеціальностей видів навчальної діяльності, спрямованих на розвиток професійних іншомовних комунікативних умінь і необхідних особистісних якостей.

Водночас побудова інформаційного суспільства, посилення ролі достовірного, вичерпного і випереджаючого знання у всіх сферах людської діяльності повною мірою охопили освіту, науку, культуру, охорону здоров'я та інші соціальні сорери. Одним із пріоритетних напрямів процесу інформатизації сучасного суспільства $€$ інформатизація освіти, під якою розуміється процес забезпечення сфери освіти методологією, технологією і практикою розробки та оптимального використання сучасних інформаційних і комунікаційних технологій, орієнтованих на реалізацію психолого-педагогічних цілей навчання і виховання.

Засоби інформаційних і комунікаційних технологій (засоби IКT) як засоби інформатизації вищої професійної освіти забезпечують оптимальне й ефективне сприйняття, засвоєння і використання навчальної інформації в інтерактивному режимі; дозволяють студентам освоювати способи діяльності в умовах доступності будь-яких локальних та глобальних інформаційних ресурсів (книг, мультимедійних навчальних програм або інформаційних мереж) [10, с. 385].

Аналіз сучасних тенденцій в розвитку української системи вищої професійної освіти, які знайшли своє відображення в Постанові Кабінету 
Міністрів України “Про затвердження Національної рамки кваліфікацій (2011р.), Указі Президента України "Про Національну стратегію розвитку освіти в Україні на період до 2021 року" (2013р.); Законі України "Про вищу освіту" (2014р.) та інших нормативно-правових актах у сфері інженерної освіти і в галузі викладання іноземних мов, дозволив визначити мету іншомовної підготовки студентів інженерно-технічних спеціальностей як сформованість професійно-іншомовної компетентності. Ї̈̈ розглядаємо як здатність і готовність майбутніх фрахівців вирішувати комунікативні завдання в сфері професійної діяльності, здійснювати іншомовне спілкування з носіями іноземної мови і виконувати пошук і аналіз інформації, необхідної для вивчення зарубіжного досвіду, а також працювати 3 науково-технічною літературою та документацією на іноземній мові в сфері обраної спеціалізації з використанням засобів інформаційних та комунікаційних технологій.

Найважливішою умовою формування професійно-іншомовної компетентності студентів інженерно-технічних спеціальностей $€$ спеціально організована навчальна діяльність із застосуванням засобів ІКТ. Інформаційно-комунікаційні технології створюють умови для роботи студентів над усіма видами іншомовної мовленнєвої діяльності (читання, письмо, аудіювання, говоріння) і для реального спілкування з носіями мови. Нині пріоритетна увага приділяється інформаційній складовій у викладанні іноземних мов [9, с. 106]. Використання мережі Інтернет дає змогу розширити доступ студентів і викладачів до автентичних матеріалів: технічних текстів 3 різних спеціальностей, електронних версій газет і журналів, словників, енциклопедій тощо.

У сучасних умовах використання засобів ІКТ стає все більш популярним серед викладачів іноземних мов і $€$ невід'ємною частиною освітнього процесу, що пояснюється такими чинниками:

- мережа Інтернет стає все доступнішою вдома та у закладах вищої освіти; будучи інструментом спілкування, вона особливо підходить для реалізації комунікативного і проблемного підходу до навчання;

- виросло нове покоління студентів, для яких використання комп'ютера та інформаційних технологій є частиною їхнього повсякденного життя. 3'явилися навіть терміни для позначення цього покоління: dot.com generation i the Net generation [5, с. 7].

Розвиток комп'ютерних технологій, з одного боку, і методики викладання іноземних мов - з іншого, спричинили появу нової галузі знань - комп'ютерної лінгводидактики. Комп'ютерна лінгводидактика вивчає теорію і практику використання інформаційних та комунікаційних технологій в навчанні мови [6, c. 244]. Одним 3 напрямків досліджень в комп'ютерній лінгводидактиці $€$ дослідження інтеграції ІКТ в загальний процес навчання іноземної мови і розробка прийомів використання інформаційних та комунікаційних технологій в освітньому процесі. Комп'ютерним матеріалам властива інтерактивність, яка виявляється в можливості участі в роботі студента і комп'ютера як рівних партнерів і передбачає свідому активність студентів інженерно-технічних 
спеціальностей, підкріплену керуючою діяльністю комп'ютера [1, с. 20].

Значним потенціалом для вирішення проблеми підвищення якості іншомовної освіти студентів інженерно-технічних спеціальностей в умовах скорочення кількості аудиторних занять мають інструменти електронного навчання: компоненти інформаційно-освітнього середовища (вікі, форум, чат, глосарій, портфоліо, онлайн-оголошення, завдання, тести); навчальні інтернетресурси (Hotlist, multimedia scrapbook, treasure hunt, subject sampler i webquest), освітні ресурси мережі Інтернет, нові інтернет-сервіси (вікі-сторінка, сайт і блог викладача) [4, с. 12]. Тобто, інформатизація вищої професійної освіти на сучасному етапі передбачає перенесення акценту від комп'ютера як технічного засобу навчання до реальної мовної діяльності за допомогою мережі Інтернет.

Тому припускаємо, що в умовах інформатизації вищої професійної освіти, формування профресійної іншомовної компетентності студентів інженернотехнічних спеціальностей необхідним є використання діагностичних, тестових програм; програмних засобів Microsoft: MS Word, MS Excel, MS Power Point для створення презентацій та інших матеріалів (графіки, діаграми, кросворди, складання буклетів); професійно спрямованих аудіо- та відеокурсів і мультимедійних навчальних CD-програм; інформаційних ресурсів мережі Інтернет для освітніх цілей (пошукові системи (www.google.com, www.ask.com); довідкових матеріалів (електронних та онлайн словників (www.dictionary.com, www.abbyylinguo.com), енциклопедій (www.britannica.com, www.wikipedia.org, www.encyclopedia.com), програм-перекладачів тощо); електронних бібліотек; віртуальних музеїв, виставок та інших наочних матеріалів; електронних версій газет і журналів, методичних матеріалів для викладачів); засобів телекомунікацій, зокрема електронної пошти, чату тощо.

Поряд зі згаданими технологіями також важливо особливу увагу приділяти застосуванню нових Інтернет-технологій, серед яких "вікі” і “блог” як прикладів сервісів Web 2.0. Характерними ознаками технологій "вікі” і “блог” $€$ простота використання, багатофункціональність і унікальність, яка полягає в можливості створення творчих проектів у межах освітнього процесу. Вони дозволяють поряд з текстовою інформацією активно використовувати графрічну інформацію, звукові файли і відеозаписи, що активізує всі канали надходження інформації, підвищує інтелектуальну активність студентів .

Висновки та перспективи подальших розвідок. Оптимізація іншомовної підготовки студентів інженерно-технічних спеціальностей передбачає необхідність урахування характеру і результатів виконуваної інженером роботи, аксіологічних аспектів інженерної діяльності; відбору відповідного змісту, освітніх технологій та видів навчальної діяльності, що інтегрують в іноземні мови і спеціальність. Ефективне фрормування професійно-іншомовної компетентності студентів інженерно-технічних спеціальностей забезпечується використанням засобів інформаційних та комунікаційних технологій. Професійно-іншомовна компетентність дозволяє вирішувати комунікативні завдання в сфрері професійної діяльності, здійснювати іншомовне спілкування з носіями іноземної мови і виконувати 
пошук і аналіз інформації, необхідної для вивчення зарубіжного досвіду в сорері обраної спеціалізації з використанням засобів інфрормаційних та комунікаційних технологій. Це зумовлює необхідність розробки теоретикометодологічних основ міждисциплінарного підходу в іншомовній освіті і практиці предметно-інтегрованого іншомовного навчання.

\section{Використана література:}

1. Бобрицька, В. І., Процька, С. М., 2019. 'Організаційно-педагогічні умови використання електронних навчальних курсів в освітньому процесі закладів вищої освіти України', Вісник Національного авіамійного університету. Серія: Педагогіка. Психологія: зб. наук.праць, Київ: Вид-во Наи. авіаи. ун-ту “НАУ-друк”, № 15, С. 19-24.

2. Джурило, АП., 2014. 'До питання “реформування” як однієї з ключових дефініщій у галузі освіти', Метод. зб. Інституту інноваційних технологій $і$ змісту освіти МОН Украӥни, Київ, Вип. 82. C. 81-87.

3. Загородна О. Ю., 2010. 'Формування комунікативної професійної компетентності студентів економічних спеціальностей засобами інноваційних технологій'. Автореферат дисертації кандидата наук, Вінниця, Вінницький державний педагогічний університет імені Михайла Коцюбинського, 20с.

4. Колос, К. Р., 2011. 'Система MOODLE як засіб розвитку предметних компетентностей учителів інформатики в умовах дистанційної післядипломної освіти', Автореферат дисертації кандидата наук, Інститут інформачійних технологій $і$ засобів навчання НАПН Украйни, Київ, 22 с.

5. Матвійчук, Л. А., 2014. 'Формування професійних знань майбутніх інженерів-програмістів засобами інформаційно-комунікаційних технологій'. Автореферат дисертації наук. Житомир, Житомирський державний університет імені Івана Франка, 21 с.

6. Паридуха, О. Ю., 2007. 'Технологія контекстного навчання при вивченні іноземної мови студентами економічних спеціальностей', Наукові записки Вінниџького державного педагогічного університету ім. М. Коцюбинського. Серія: Педагогіка і психологія, Вінниця. Випуск 21. С. 242-246.

7. Полякова, Л. О., 2015. 'Зачем инженеру иностранный язык? (Анализ профессиональных стандартов) '. Современные проблемы науки и образования. № 6-0. С. 371-380.

8. Седов, В. С., 2016. 'Формування фахової компетентності майбутніх інженерів-програмістів в умовах магістратури'. Дисертаиія кандидата наук. Херсон, Херсонський державний університет, $240 \mathrm{c}$.

9. Dudeney, G. \& Hockly, N. 2007, 'How to Teach English with Technology', UK : Pearson Education Limited, $285 \mathrm{p}$.

10. Wegener, R. \& Leimeister J., 2012. 'Virtual Learning Communities: Success Factors and Challenges', International Journal of Technology Enhanced Learning (IJTEL). Number: 5/6, Vol. 4. P.383-397.

\section{References:}

[1] Bobrytska, V. I., Protska, S. M., 2019. 'Orhanizatsiino-pedahohichni umovy vykorystannia elektronnykh navchalnykh kursiv v osvitnomu protsesi zakladiv vyshchoi osvity Ukrainy, Visnyk Natsionalnoho aviatsiinoho universytetu. Seriia: Pedahohika. Psykholohiia: zb. nauk.prats, Kyiv: Vyd-vo Nats. aviats. un-tu "NAU-druk", № 15, S. 19-24.

[2] Dzhurylo, AP., 2014. 'Do pytannia "reformuvannia" yak odniiei z kliuchovykh definitsii u haluzi osvity, Metod. zb. Instytutu innovatsiinykh tekhnolohii i zmistu osvity MON Ukrainy, Kyiv, Vyp. 82. S. 81-87.

[3] Zahorodna O. Yu., 2010. 'Formuvannia komunikatyvnoi profesiinoi kompetentnosti studentiv ekonomichnykh spetsialnostei zasobamy innovatsiinykh tekhnolohii. Avtoreferat dysertatsii kandydata nauk, Vinnytsia, Vinnytskyi derzhavnyi pedahohichnyi universytet imeni Mykhaila Kotsiubynskoho, 20s.

[4] Kolos, K. R., 2011. 'Systema MOODLE yak zasib rozvytku predmetnykh kompetentnostei uchyteliv informatyky v umovakh dystantsiinoi pisliadyplomnoi osvity, Avtoreferat dysertatsii kandydata nauk, Instytut informatsiinykh tekhnolohii i zasobiv navchannia NAPN Ukrainy, Kyiv, $22 \mathrm{~s}$.

[5] Matviichuk, L. A., 2014. 'Formuvannia profesiinykh znan maibutnikh inzheneriv-prohramistiv zasobamy informatsiino-komunikatsiinykh tekhnolohii. Avtoreferat dysertatsii nauk. Zhytomyr, Zhytomyrskyi derzhavnyi universytet imeni Ivana Franka, 21 s. 
[6] Parydukha, O. Yu., 2007. 'Tekhnolohiia kontekstnoho navchannia pry vyvchenni inozemnoi movy studentamy ekonomichnykh spetsialnostei, Naukovi zapysky Vinnytskoho derzhavnoho pedahohichnoho universytetu im. M. Kotsiubynskoho. Seriia: Pedahohika i psykholohiia, Vinnytsia. Vypusk 21. S. 242246.

[7] Polyakova, L. O., 2015. 'Zachem inzheneru inostrannyi yazyk? (Analiz professionalnyh standartov)'. Sovremennye problemy nauki i obrazovaniya. № 6-0. S. 371-380.

[8] Sedov, V. Ye., 2016. 'Formuvannia fakhovoi kompetentnosti maibutnikh inzheneriv-prohramistiv v umovakh mahistratury. Dysertatsiia kandydata nauk. Kherson, Khersonskyi derzhavnyi universytet, $240 \mathrm{~s}$.

[9] Dudeney, G. \& Hockly, N. 2007, 'How to Teach English with Technology', UK : Pearson Education Limited, $285 \mathrm{r}$.

[10] Wegener, R. \& Leimeister J., 2012. 'Virtual Learning Communities: Success Factors and Challenges, International Journal of Technology Enhanced Learning (IJTEL). Number: 5/6, Vol. 4. P. 383-397.

\section{СЛАБКо В.Н., ЗАПОЛЬСЬКА Ю. А. Формирование профессиональной иноязычной компетентности студентов инженерно-технических специальностей в условиях информатизации высшего профессионального образования.}

В современных условиях информатизаиии образования существует необходимость пересмотра целей, содержсания и технологии обучения иностранным языкам, разработки многоуровневой личностно ориентированной иноязычной подготовки студентов с применением информационно-коммуникационных технологий и формирования в учреждениях высшего образования активного информационно-учебного языковой среды.

Определены научно-педагогическую проблему - формирование профессиональной иноязычной компетентности студентов инженерно-технических специальностей как способности к деловой и межнличностной интеракиии в поликультурной среде

Анализ последних исследований и публикаиий. Теоретические и практические аспекты формирования профессиональной иноязычной компетентности студентов исследовали М.Винник, Л. Гриико, В. Осадчий, Т. Хаткинсон (T. Hutchinson). Теоретические вопросы коммуникации исследовали M. Каган, C. Спенсер (S. Spencer), K. Финч (K. Finch.). В том числе и в сфере информационных технологий - C. Джконсон (S. Johnson) и Л. Розенкрени (L. Rosencrance). Однако, научных изысканий, посвященных анализу проблемы формирования профессионально-иноязычной компетентности будущих инженеров в условиях информатизации, не стали предметом пристального научного интереса ученых.

В исследовании поставлена задача провести анализ проблемь формирования профессиональноиноязычной компетентности будущих инженеров с использованием средств информационных и коммуникационных технологий в условиях информатизачии высшего образования.

Информатизацию образования рассмотрено как проиесс обеспечения сферы образования методологией, технологией и практикой разработки и оптимального использования современньх информационных и коммуникащионных технологий, ориентированных на реализаиию психологопедагогических челей обучения. Поэтому в статье выявлены возможности применения средств информационных и коммуникационных технологий в процессе формирования профессиональноиноязычной компетентности студентов инженерных спечиальностей. Обоснована необходимость использования средств информационных и коммуникачионных технологий на профильноориентированных занятиях по иностранному языку и в иикле профессиональных диспиплин, в прочессе выполнения курсовых и выпускных квалификаимонных работ, подготовке к участию в конференциях и международных проектах.

Эффективное формирование профессионально-иноязычной компетентности студентов инженерно-технических спецуиальностей обеспечивается использованием средств информационныхх и комхуникационных технологий. Профессионально-иноязычная компетентность позволяет решать коммуникативные задачи в сфере профессиональной деятельности, осуществлять иноязычное общение с носителями иностранного языка и выполнять поиск и анализ информащии, необходимой для будущей деятельности.

Ключевые слова: профессиональная иноязычная компетентность, студенты инженернотехнических специальностей, информационно-коммуникационные технологии, информатизация выстего профессионального образования. 
SLABKo $V$. N., ZaPOLSKA YU. A. Formation of professional foreign language competence of engineering and technical students in the context of digitalization of higher professional education.

Research topicality. Modern conditions of digitalization of education provide for a need to reconsider the purpose, content and technology of foreign language teaching, development of multilevel personality-oriented foreign language training of students using information and communication technologies and establishment of active information and educational language environment in higher educational institutions.

Problem statement. The scientific and pedagogical problem - development of professional foreign language competence of engineering and technical students as the ability for business and interpersonal interaction in the multicultural environment is outlined.

Review of recent research and publications. Theoretical and practical aspects of the development of professional foreign language competence of students were studied by M. Vinnyk, L. Hrishko, V. Osadchyi, T. Hutchinson. Theoretical issues of communication were studied by M. Kahan, S. Spencer, K. Finch,in particular in the field of information technology - S. Johnson and L. Rosencrance. However, no scholars closely studied the analysis of the problem of development of professional and foreign language competence of future engineers in the conditions of digitalization.

Setting objectives. The study is intended to analyse the problem of the development of professional and foreign language competence of future engineers using information and communication technologies in the context of digitalizationof higher education.

Results. Digitalization of education is considered as a process of providing the field of education with methodology, technology and practice of development and optimal use of modern information and communication technologies focused on the realization of psychological and pedagogical learning goals. Therefore, the article identifies the possibilities of using information and communication technologies in the process of developing professional and foreign language competence of engineering students. The need of using information and communication technologies in specialized foreign language classes and in the cycle of professional subjects, in the process of preparing term and final qualification papers, preparing for participation in conferences and international projects is substantiated.

Conclusions. Effective formation of professional and foreign language competence of engineering and technical students is ensured by the use of information and communication technologies. Specialized foreign language competence allows solving communicative objectives in the field of professional activity, carrying out foreign language communication with native speakers of a foreign language and performing search and analysis of information necessary for future activity.

Keywords: professional foreign language competence, engineering and technical students, information and communication technologies, digitalizationof higher professional education.

DOI: https://doi.org/10.31392/NZ-npu-144.2019.21

УДК $378: 14$

Сливка Б. С.

\section{ФОРМУВАННЯ ХРИСТИЯНСЬКОЇ МОРАЛІ ДОШКІЛЬНИКІВ НАПРИКІНЦІ XX - НА ПОЧАТКУ XXI СТОЛІТТЯ: УЗАГАЛЬНЕННЯ МОЖЛИВОСТЕЙ ВИКОРИСТАННЯ ІСТОРИЧНОГО ДОСВІДУ}

Обгрунтовано концептуальні підходи до формування християнської моралі дошкільників у період незалежності украӥнської держави. Визначено основні детермінанти пастирської роботи з дітьми дошкільного віку (антропологія пастирства, пастирська психологія, пастирська педагогіка, дошкільна освіта, дошкільне виховання, сімейно-родинна освіта, сімейно-родинне виховання, иерковний спів тошо). Виокремлено чинники впливу на розвиток формування християнської моралі доикільників (ідеологічні, 